\title{
Faktor Pendorong Perkembangan Confucius Institute di Amerika Serikat
}

\author{
Fikri Fendi Ferdiansyah \\ Universitas Airlangga
}

\begin{abstract}
ABSTRAK
Perkembangan Confucius Institute sebagai lembaga pendidikan bahasa dan budaya China di Amerika Serikat sangatlah pesat. Fenomena ini merupakan sebuah anomali karena jumlah penduduk Asia terutama yang berkebangsaan China di Amerika Serikat tidak banyak, disertai dengan tantangan, kendala, serta anomali lainnya yang seharusnya menyebabkan Confucius Institute tidak dapat berkembang dengan pesat. Tulisan ini lantas berusaha menjelaskan mengapa Confucius Institute dapat berkembang dengan pesat hanya dalam kurun waktu 10 tahun. Penelitian dilakukan berfokus pada dua hal, yaitu hubungan antara institusi, home country dan host country melalui bargaining model; serta penerapan strategi adaptasi dengan marketing mix. Hasil analisis penulis menunjukkan bahwa keberhasilan internasionalisasi Confucius Institute di Amerika Serikat terjadi karena kedekatan hubungan antara home country dan host country dalam bidang pendidikan bahasa sehingga tercipta berbagai kerjasama bilateral yang mendukung eksistensi Confucius Institute; kedekatan institusi dengan host country berdasarkan pada bargaining power; serta penerapan strategi marketing mix $4 P$ 's dan $4 C$ 's.
\end{abstract}

Kata-Kata Kunci: internasionalisasi pendidikan, Confucius Institute, bargaining model, marketing mix

Confucius Institute is an educational learning Chinese language institution, integrated within the China Ministry of Education which have the task to internationalizing Chinese education in many states. The Confucius Institute itself has grown rapidly in the United States in the past ten years. Regarding this phenomenon, there are many anomalies which make Confucius Institute should not become bloomed in there, such as the Chinese-Americans or Chinese spoken are minorities in the United States. This paper tried to explain why the Confucius Institute can easily outspread in the United States during this past ten years. This research focused on two things: (1) the relationship between the institution, home country, and host country through bargaining model concept and (2) the application of adaptation strategy with the marketing mix. The author found that the success of Confucius Institute in the United States is because there's a mutually close relationship between the home country and host country based on bilateral agreement; the mutual close relationship between institution and host country based on bargaining power; and the application of marketing mix based on $4 P^{\prime}$ 's and $4 C^{\prime}$ 's.

Keywords: internationalization of education, Confucius Institute, bargaining model, marketing mix 


\section{Fakta dan Anomali Perkembangan Confucius Institute di Amerika Serikat}

Confucius Institute sebagai sebuah lembaga pendidikan bahasa dan budaya China telah mengalami peningkatan jumlah unit yang signifikan di Amerika Serikat sejak pertama kali diresmikan pada tahun 2004 oleh Kementrian Pendidikan Republik Rakyat China dengan kantor pusat Headquarter of Confucius Institute (Hanban) di Beijing. Hingga saat ini terdapat setidaknya terdapat 500 unit Confucius Institute dan 1000 Confucius Classroom yang tersebar di seluruh dunia sejak pertama kali dibuka di Korea Selatan pada tahun 2004 (Hanban $t, t$ ). Pendirian lembaga pendidikan dan budaya yang terintegrasi oleh Kementrian Pendidikan China bukanlah tanpa alasan, terdapat beberapa motif yang melatar belakangi pendirian institusi tersebut dalam skala global. Salah satunya adalah motif Diplomasi Budaya oleh pemerintah China, hal tersebut sesuai dengan pernyataan Kementerian Pendidikan China tahun 2012 tentang tujuannya didirikan lembaga Confucius Institute (dalam Pan 2013, 24) :

".. to developing Chinese language and culture teaching resources and making its services available worldwide, meeting the demands of overseas Chinese learners to the utmost degree, and contributing to global cultural diversity and harmony".

China memilih Confucius Institute sebagai salah satu tools yang penting pada diplomasi budayanya, bertepatan dengan agenda pemerintah untuk memperkenalkan konsep Neo- confusianisme dalam skala global. Sejak tahun 1980an telah dilakukan diskusi untuk mengangkat kembali konsep konfusianisme sebagai ideologi alternatif China setelah sebelumnya ditinggalkan akibat kebijakan revolusi budaya pada era Mao Zedong yang melarang segala bentuk pembelajaran dogmatisme selain ideologi maoisme. Pertumbuhan ekonomi yang sangat cepat dan peningkatan kesejah-teraan masyarakat yang tinggi pada negara China pada era peme-rintahan Deng Xiaoping dianggap oleh pemerintahan China sendiri merupakan implementasi dari budaya konfusianisme yang terpartri dalam diri masyarakat China (Berger 2004, 189). Sejak saat itu konfusianisme menjadi sebuah studi dalam menjelaskan fenomena East Asia Miracle, bahwa negara-negara Asia Timur menjadi negara maju dikarenakan kontribusi implementasi budaya konfusianisme yang menjadi nilai luhur masyarakat Asia Timur. Pada tahun 1994 pemerintah China dalam konferensi International Confucius Association menyatakan bahwa: “....while China had benefitted from confucianism, it was also possible for the west". 
Hal tersebut menjadi tonggak pertama kebijakan China untuk mencoba menyebarkan konsep konfusianisme dalam skala global. Terdapat berbagai pendapat mengenai keinginan China untuk memperkenalkan konfusianisme, bahwa China mempropagandakan nilai luhur konfusianisme dalam hal pendidikan sebagai antitesis dari ideologi demokrasi liberal barat bertepatan setelah Amerika Serikat menjadi negara pemenang pada setelah Perang Dingin (Berger 2004, 189). Hingga pada tahun 2004 dibentuklah Confucius Institute dibawah Menteri Pendidikan China menjadikan semakin jelas terlihat bahwa China bersungguh-sungguh dalam agendanya tersebut.Menteri Pendidikan China, Zhou (2003-2009) menegaskan bahwa Confucius Institute merupakan salah satu instrumen dalam meningkatkan soft power China:“.....it helps Chinese higher education gain international recognition for its delivery of educational services in the global market and expand Chinese influence worldwide".

Confucius Institute sebagai salah satu tool dalam diplomasi budaya China kemudian menjadi salah satu indikator dalam meningkatkan soft power China. Internasionalisasi pendidikan bahasa dan budaya China melalui Confucius Institute kemudian mulai dilakukan secara masif. Tiap tahun selalu ada peningkatan unit Confucius Institute dalam skala global, terutama pada negara Amerika Serikat. Hingga tahun 2012 tercatat 655.000 murid yang teregistrasi untuk mengikuti pembelajaran di Confusius Institute.

\section{Gambar 1. Persebaran Confucius Institute di Level Global}

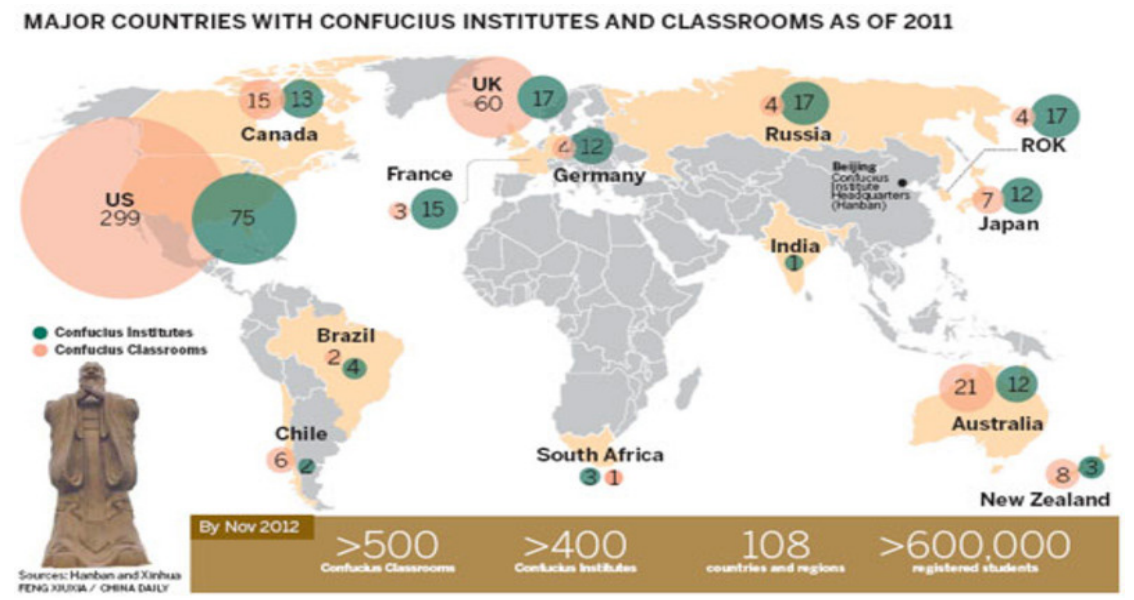

Sumber:http://usa.Chinadaily.com.cn/China/attachement/jpg/ site1/20121203/0023ae9885da1226292d19.jpg 
Dalam tingkat global, Amerika Serikat merupakan negara dengan jumlah unit Confucius Institute terbanyak, pada tahun 2011 dari 465 unit terdapat kurang lebih 75 Confucius Institute dengan 299 Confucius Classroom berdiri dengan tren peningkatan jumlah unit tiap tahunnya yang cukup signifikan. Seperti yang ada dalam diagram dibawah, hingga pada tahun 2011 terdapat sekitar 70 unit lebih Confucius Institute yang terdapat di Amerika Serikat dengan berafiliasi pada Universitas-Universitas di beberapa negara bagian. Amerika Serikat juga merupakan negara yang memiliki tingkat peningkatan unit Confucius Institute yang tertinggi jika dibandingkan dengan negara atau benua lainnya yang bekerjasama dengannya. Selain itu unit Confucius Institue dalam melakukan aktivitasnya bukan merupakan lembaga yang sepenuhnya independen sebagaimana institut bahasa lainnya misalnya seperti the British Council, the Goethe Institut, maupun Institute Francais, melainkan terlebih dahulu bekerjasama dengan universitas pada negara yang ingin bekerjasama (Host Country University) dengan persetujuan dan pengelolaan dari Confucius Institute Headquarter (Hanban) di Beijing (Zaharna 2014, 15).

\section{Gambar 2. Diagram Peningkatan Unit Confucius Institute di Amerika Serikat}

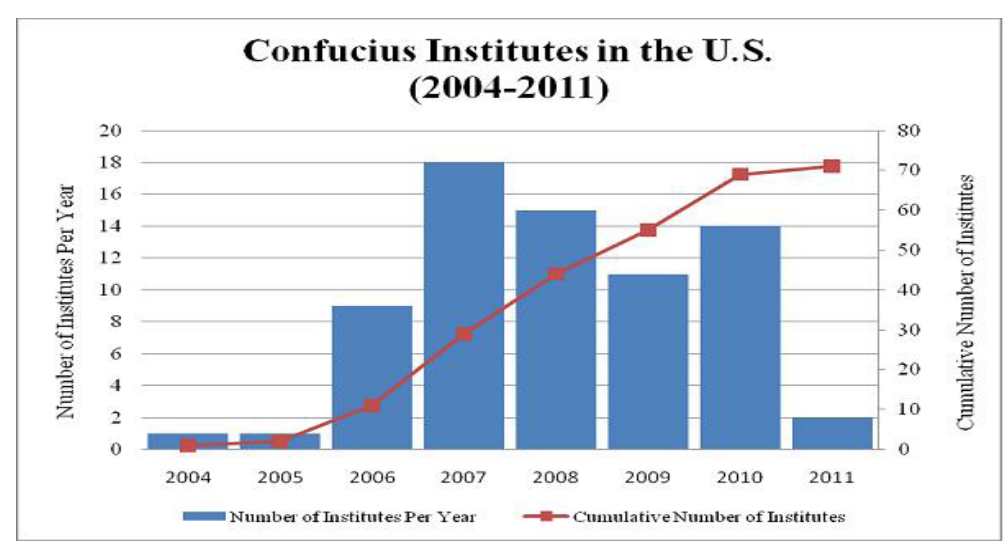

Sumber: https://blogs.nottingham.ac.uk/Chinapolicyinstitute/ files/2012/05/CI-trend.jpg

Namun perkembangan Confucius Institute hingga menjadi lembaga bahasa asing terbesar di Amerika Serikat saat ini pada dasarnya tidak terlepas dari berbagai risiko. Dari sisi geografi, jarak antara China dan Amerika Serikat cukup jauh sehingga tentunya operational cost nya juga besar.Pandangan masyarakat Amerika Serikat mengenai China sebagai calon konsumen juga terbelah menjadi dua. Pada tahun 2004, bertepatan dengan berdirinya Confucius 
Instituteyang pertama diAmerika Serikat, ketidaksukaan masyarakat terhadap negara China secara keseluruhan berada pada persentase 54\%, dengan tingkat 'tidak suka' sebesar 38\% dan tingkat 'sangat tidak suka' mencapai angka 16\% (Gallup Poll t,t). China juga dinilai sebagai ancaman bagi Amerika Serikat oleh masyarakat Amerika Serikat baik secara ekonomi dan militer dengan persentase sebesar 50-64\% di tahun 2004-2005 (Gallup Poll t,t). Hal ini tentunya menjadi kendala di kondisi awal berdirinya Confucius Institute ketika masyarakat Amerika Serikat sebagai calon konsumen bagi Confucius Institute ternyata memiliki pandangan negatif terhadap China, apalagi Confucius Institute berintegrasi langsung dengan pemerintah China.

Penulis juga menemukan adanya anomali lainnya berdasarkan populasi dan letak wilayah penduduk di Amerika Serikat yang menggunakan bahasa mandarin pada masa awal Confucius Institute pertama kali berdiri. Tahun 2004, populasi penduduk beretnis China (American-Asia) ditambah dengan imigran yang berasal dari China tidak banyak jika dibandingkan dengan populasi berkebangsaan lain seperti imigran yang berasal dari Mexico dan India (Jennewein 2015). Ditambah lagi, tidak banyak wilayah federasi di Amerika Serikat yang ditempati oleh penduduk berbahasa China, peta dibawah menggambarkan negara bagian mana saja yang populasi penduduk beretnis dan berbahasa China tersebar.

\section{Gambar 3. Peta Persebaran penduduk Amerika Serikat beretnis China}

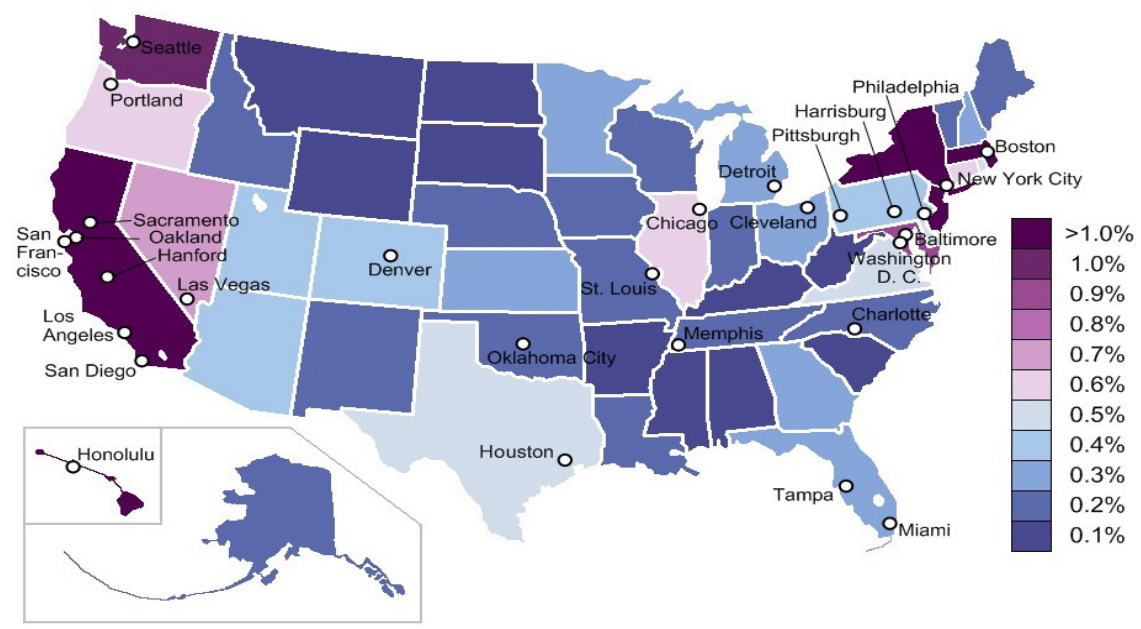

Sumber: http://nyzusa.com/chinese-population-in-theunited-states/ 
Dari seluruh wilayah federasi Amerika Serikat, hanya beberapa saja wilayah yang tingkat penduduk-penduduk beretnis dan berbahasa China paling tinggi dari wilayah lain, seperti di kawasan New York, Massachusetts, New Jersey, Washington, California dan Hawaii. Namun meskipun dikatakan paling tinggi, populasi etnis China di wilayah tersebut masih terbilang minoritas, hanya lebih dari satu persen dari total penduduk di masing-masing wilayah tersebut yang beretnis China. Seperti pada wilayah California yang memiliki populasi etnis China terbesar sekitar 1.514.535 dari total penduduk California yang berjumlah 38,8 juta. Ini berarti bahasa China yang digunakan pun masih minoritas di wilayah yang memiliki persentase populasi etnis China paling tinggi sekalipun.

\section{Tabel 1. Bahasa-bahasa asing yang dipelajari oleh mahasiswa di Amerika Serikat.}

Top 15 Languages Learned in the U.S.

(based on Fall 2006 Enrollments in U.S. Institutions of Higher Education)

\begin{tabular}{ll|}
\hline Language & $\begin{array}{l}\% \text { of } \\
\text { Enrollment }\end{array}$ \\
\hline 1. Spanish & $52.2 \%$ \\
\hline 2. French & $13.1 \%$ \\
\hline 3. German & $6 \%$ \\
\hline 4. American Sign Language & $5 \%$ \\
\hline 5. Italian & $5 \%$ \\
\hline 6. Japanese & $4.2 \%$ \\
\hline 7. Chinese & $3.3 \%$ \\
\hline 8. Latin & $2 \%$ \\
\hline
\end{tabular}

\begin{tabular}{|c|c|}
\hline Language & $\begin{array}{l}\% \text { of } \\
\text { Enrollment }\end{array}$ \\
\hline 9. Russian & $1.6 \%$ \\
\hline 10. Arabic & $1.5 \%$ \\
\hline 11. Ancient Greek & $1.4 \%$ \\
\hline 12. Biblical Hebrew & $0.9 \%$ \\
\hline 13. Portuguese & $0.7 \%$ \\
\hline 14. Modern Hebrew & $0.6 \%$ \\
\hline 15. Korean & $0.5 \%$ \\
\hline
\end{tabular}

Sumber: http://www.utexas.edu/cola/tlc/news/article. php?id=2995

Pada tahun 2006, bahasa China masih menjadi bahasa yang kurang diminati untuk dipelajari bagi kalangan mahasiswa atau pelajar di Amerika Serikat. Tabel diatas menunjukkan bahasa China berada di tingkat posisi ke-7 dari 15 macam bahasa asing yang dipelajari oleh kalangan Pendidikan Tinggi di Amerika Serikat atau hanya sekitar $3,3 \%$ yang mengikuti dan memiliki minat untuk belajar bahasa mandarin. Tentu hal ini menjadi anomali bahwa pada awalnya kalangan pelajar Amerika Serikat sendiri yang menjadi target utama dari Confucius Institute tidak memiliki minat yang besar untuk belajar bahasa China, perkembangan Confucius Institute pun yang berdiri sejak 2004 hingga tahun 2006 juga berjalan dengan lambat yaitu hanya sekitar 10 unit Confucius Institute yang ada di Amerika Serikat, sangat berbeda dengan pertumbuhan tahun- 
tahun setelahnya yang meningkat drastis hingga pada tahun 2011 Confucius Institute di Amerika Serikat mencapai 75 unit (Scotton 2015).

Hubungan antara China dengan Amerika Serikat sendiri jugatidak dapat dikatakan harmonis, tidak juga hostile baik secara ekonomi, politik maupun militer. Meskipun hubungan ekonomi berjalan cukup dinamis dengan melihat dari banyaknya FDI (Foreign Direct Investment) yang keluar masuk dari kedua negara tersebut, namun sering terjadi isu maupun fenomena-fenomena yang kerap mengakibatkan hubungan antara Amerika Serikat dengan China menjadi tegang, diantaranya seperti konflik Laut China Selatan dan Laut China Timur, klaim ADIZ (Air Defence Identification Zone) oleh China, depresiasi nilai mata uang Yuan/RMB, perbedaan pandangan mengenai status Taiwan dan ancaman nuklir Korea Utara, serta tingginya kasus pembajakan IPR (Intellectual Property Rights) yang dilakukan oleh China terhadap industri-industri yang berasal Amerika Serikat (Task Force 2007). Dengan kata lain, hubungan antara kedua negara ini merupakan love-hate relationship, yang mana meskipun kedua negara dapat menjalankan hubungan yang baik di sektor tertentu namun rentan akan terjadi kerenggangan dan ketegangan ketika terdapat suatu permasalahan yang timbul (Topping 2011)

Dari berbagai tantangan dan anomali diatas, perkembangan Confucius Institute ternyata tetap berjalan lancar dan semakin meningkat. Hingga tahun 2015 Confucius Institute mendominasi lembaga bahasa asing internasional milik pemerintah lainnya yang memiliki kuantitas unit terbesar seperti yang digambar pada tabel dibawah. Sejak didirikan pada tahun 2004 oleh Kementrian Pendidikan China, Confucius Institute telah memiliki 109 Unit dan 347 Unit Confucius Classroom di Amerika Serikat. Hal tersebut seperti yang terlihat pada tabel dibawah.

\section{Tabel 2. Jumlah Unit Lembaga Bahasa Internasional yang} dibentuk Pemerintah di Amerika Serikat

\begin{tabular}{|l|c|c|c|c|}
\hline $\begin{array}{c}\text { Lembaga } \\
\text { Bahasa } \\
\text { Internasional }\end{array}$ & $\begin{array}{c}\text { Institute } \\
\text { Francais }\end{array}$ & $\begin{array}{c}\text { Instituto } \\
\text { Cervantes }\end{array}$ & $\begin{array}{c}\text { Goethe } \\
\text { Institute }\end{array}$ & $\begin{array}{c}\text { Confucius } \\
\text { Institute \& } \\
\text { Confucius } \\
\text { Classroom }\end{array}$ \\
\hline Negara Asal & Prancis & Spanyol & Jerman & China \\
\hline Tahun Berdiri & 2011 & 1991 & 1951 & 2004 \\
\hline Jumlah Unit & 2 & 6 & 6 & $\begin{array}{c}109 \text { CI dan } 347 \\
\text { CC }\end{array}$ \\
\hline
\end{tabular}

Sumber: Data diolah dari situs resmi masing-masing institusi 
Dari anomali tersebut penulis berusaha memberi penjelasan mengapa kemudian Confucius Institute di Amerika Serikat dapat berkembang dengan pesat melalui hubungan bargain Amerika Serikat, China dan Confucius Institute melalui teori Two Tier Bargaining Model dan strategi pemasaran yang dilakukan Confucius Institute di Amerika Serikat melalui Marketing Mix 4P's dan 4C's.

\section{Hubungan Bargain (Two Tier Modified Bargaining Model) Amerika Serikat, China dan Confucius Institute}

Secara umum Two-tier Modified Bargain Model merupakan ekstensi dari One-Tier Bargain Model yang menggambarkan aktivitas internasionalisasi yang dilakukan perusahaan home country dengan host country dengan berfokus pada hubungan kerjasama yang dilakukan antara pemerintah home country dengan pemerintah host country. Konsep Two-tier Modified Bargain Model yang kemudian dikembangkan oleh Ramamurti (2001, 23-39) mencakup tidak hanya hubungan antara pemerintah home country dan host country, namun juga interaksi yang terjadi antara perusahaan home country dengan pemerintah home country. Sehingga dalam Two tier Modified Bargain Model terdapat dua bentuk interaksi, yaitu hubungan antara pemerintah home country dan pemerintah host country, dan hubungan perusahaan home country dengan host country.

\section{Hubungan Bargain Amerika Serikat dan China}

Penulis kemudian menjelaskan terlebih dahulu hubungan antara Amerika Serikat sebagai host country dan China sebagai home countrydari Confucius Institute melalui kedekatan kedua negara dengan melihat kunjungan antar Pemimpin Negara hingga terciptanya nota kerjasama bilateral yang disetujui kedua negara. Hubungan diplomatik resmi antara Amerika Serikat dengan Republik Rakyat China dimulai pada tahun 1979 atau 30 tahun sejak China daratan dikuasai oleh Mao Zedong. China yang pada masa itu menjalankan kebijakan keterbukaan perdagangan yang diprakarsai oleh Deng Xiaoping mulai menjalankan aktifitas bisnis dengan Amerika Serikat baik dalam bidang ekspor maupun impor sehingga normalisasi hubungan antara China dengan Amerika Serikat yang sempat menegang pada era Mao Zedong berjalan dengan baik. Sejak saat itu hubungan diplomatik antara Amerika Serikat dengan China semakin baik ditandai dengan beberapa kunjungan pemimpin antar negara. Presiden George W. Bush berkunjung ke China dan bertemu dengan Presiden Jiang Zemin pada tahun 2002 untuk membahas langkah-langkah penanganan terorisme, salah satunya adalah 
melalui pengembangan pendidikan bahasa asing (The White House 2002).

Pada tahun 2006 Presiden Hu Jintao mengunjungi Amerika Serikat, pertemuan tersebut menghasilkan kesepakatan kedua negara untuk meningkatkan kerjasama dalam hal pendidikan melalui U.S.-China Education Agreement for Cooperation in Educational Exchange. Dalam kerjasama tersebut China mendukung kebijakan National Security Language Initiative Amerika Serikat serta menambah kuota dan dana untuk program pendidikan Fullbright dan meningkatkan promosi pendidikan Bahasa China di Amerika Serikat (Gill 2006). Secara umum, kesepakatan tersebut juga membahas kerjasama pendidikan bahasa, pertukaran pelajar dan beasiswa lainnya yang mana kedua negara saling mendukung segala bentuk aktifitas edukasional tersebut. Secara khusus kesepakatan tersebut membicarakan kerja sama pertukaran pelajar secara individual, pendidikan bahasa, studi grup dan delegasi, pertukaran data dan materi pendidikan dan penelitian, kooperasi dan pertukaran secara langsung, ketentuan mengenai finansial, fasilitasi studi privat, regulasi dan hukum, serta agen eksekutif. Hal ini menjadi langkah utama kedua negara dalam melakukan aktifitas kerjasama kedua negara untuk bersama-sama mengembangkan pendidikan bahasanya.

Pada tahun 2009, Menteri Pendidikan Amerika Serikat Arne Duncan bertemu dengan Wakil Kanselir China sekaligus selaku Presiden dari Dewan Hanban (Confucius Institute Headquarter) Liu Yandong untuk membahas lebih lanjut kerjasama dalam aktivitas pendidikan secara bilateral serta membicarakan mengenai Confucius Institute sebagai langkah nyata bagi pengembangan pendidikan bahasa asing di Amerika Serikat. Dalam perjanjian U.S.-China Work Plan On Education Activities tersebut, pada pasal 2 ayat 2 tertulis bahwa Departemen Pendidikan Amerika Serikat mendorong dan mendukung program-program pengajaran bahasa China dan mengembangkan pendidikan yang berkaitan dengan China di Institusi Pendidikan Tinggi Amerika Serikat, dan juga sebaliknya yang dilakukan oleh Menteri Pendidikan dari kedua belah pihak. Persetujuan ini kemudian membuktikan langkah lebih lanjut keseriusan kedua negara dalam hal kerjasama pendidikan sekaligus secara tidak langsung mendukung eksistensi Confucius Institute sebagai institusi pendidikan bahasa di dalam pendidikan tinggi Amerika Serikat.

Amerika Serikat juga menyadari untuk segera merealisasikan ambisi pemerintah untuk meningkatkan perkembangan pendidikan bahasa asing, tidak hanya bergantung pada dana dari pemerintah, 
diperlukan kerjasama baik antara pemerintah dengan sektor privat maupun dengan kerjasama pemerintah negara lain. Industri jasa pendidikan bahasa asing pada sektor privat di Amerika Serikat juga berkembangdi kisaran 5\%-10\% sejak tahun 2004 dan berkontribusi bagi pendapatan negara dengan rata-rata $0,1 \%$ dan menyerap tenaga kerja sekitar 0,12\% di tiap tahunnya (Joint National Comitte for Language 2015). Hal ini dinilai tepat oleh pemerintah Amerika Serikat untuk bekerja sama dengan pihak-pihak privat maupun negara lainnya. Pada tahun 2009 Presiden Barrack Obama menetapkan kebijakan 100.00o Strong Initiative yang menargetkan 100.000 pelajar Amerika Serikat untuk melakukan studi ke China. Hal ini kemudian diresmikan oleh Menteri Luar Negeri Hillary R Clinton pada tahun 2010 di Beijing China bersama Wakil Kanselir China Liu Yandong (U.S. Department of State 2011). Kebijakan ini kemudian disambut baik oleh Liu Yandongdengan menawarkan program beasiswa 10.000 Chinese Bridge melalui Confucius Institute yang ada di Amerika Serikat. Selain itu, Hillary juga meresmikan organisasi 100.000 Strong Foundation pada tahun 2013 yang bersifat independen dalam melaksanakan amanat dari kebijakan 100.00o Strong Initiative. Organisasi ini secara penuh mengandalkan pada kerjasama lembaga privatyang ada di Amerika Serikat yang bergerak di industri bahasa, baik dalam bentuk kerjasama program maupun dana. Adapun partner resmi dari 100.000 Strong Foundation ini adalah AASCU, American Councils for International Education, Americans Promoting Study Abroad (APSA), American University, Asia Society, CIEE, China Institute, Community Colleges for International Development (CCID), Benjamin A. Gilman International Scholarship, Hispanic Association of Colleges and Universities (HACU), I.Am.Angel Foundation, One World Now, Project Pengyou, School Year Abroad, Teach for China, Thurgood Marshall College Fund, Confucius Institute Chigago Public School dan UCLA Confucius Institute (U.S.-China Strong t,t). Dari kerja sama tersebut terkumpul dana sebesar 68 juta dollar sesuai dengan estimasi anggaran untuk implementasi program-program dari kebijakan 100.00o Strong Initiative tersebut.

\section{Hubungan Bargain Confucius Institute dan Amerika Serikat}

Hubungan antara Confucius Institute dengan masyarakat dan pemerintah Amerika Serikat mulai berkembang pada saat Presiden George W Bush menetapkan kebijakan National Security Language Initiative (NSLI) pada tahun 2006 sebagai langkah lebih lanjut darikebijakan National Security Education Program (NSEP) dalam membantu masyarakat Amerika Serikatn untuk meningkatkan 
kompetensinya pada bidang pendidikan bahasa asing, khususnya bahasa-bahasa yang termasuk dalam critical language. Kebijakan tersebut dinilai penting untuk dilakukan mengingat Amerika Serika yang dapat dikatakan paling berpengaruh pada awal abad 21, namun perkembangan pendidikan bahasa asing dalam masyarakatnya cenderung lambat jika dibanding negara kompetitor Amerika Serikat lain, terutama negara China (U.S. Department of Education 2006). Paket program dan anggaran NSLI dapat seperti yang ada pada tabel di bawah ini.

\section{Tabel 3. Program Spesifik Dalam Kebijakan NSLI}

\begin{tabular}{|l|c|c|}
\hline & FY 2007 & FY 2008 \\
\hline Department of Education & & \\
\hline Foreign Language Assistance Program (FLAP) & 24 & 26.5 \\
\hline Advancing America Through Foreign Language Partnerships & 0 & 0 \\
\hline Language Teachers Corps & 0 & 0 \\
\hline E-Learning Language Clearinghouse & 0 & 0 \\
\hline Teacher-to-Teacher Initiative & 0 & 0 \\
\hline & & \\
\hline Office of the Director of National Intelligence (DNI) & & \\
\hline STARTALK & 4.9 & 12 \\
\hline & & \\
\hline Department of Defense & & \\
\hline Expanding K-16 Pilot to 3 Programs & 3 & 3 \\
\hline Expanding the National Language Flagship Program & 11.3 & 11.2 \\
\hline National Language Corps & 6.5 & 6.5 \\
\hline & & \\
\hline Department of State & & \\
\hline Intensive Summer Language Institutes & 6 & 9 \\
\hline Gilman Scholarship Enhancement & 1.1 & 1.1 \\
\hline Fulbright Student Program Enhancement & 1.5 & 1.5 \\
\hline Fulbright Foreign Language Teaching Assistant Program (FLTA) & 5 & 5 \\
\hline High School Teacher Exchange & 0.9 & 1.5 \\
\hline High School Summer Language Institutes & 1.3 & 5 \\
\hline High School Semester and Year Abroad & 0 & 3.6
\end{tabular}

Source: National Security Language Initiative (NSLI) Budget Information http://www2.ed.gov/about/inits/ed/competitiveness/nsli/funding.html

Sejalan dengan kebijakan pemerintah untuk mengembangan pendidikan bahasa asing tersebut, Confucius Institute di Amerika Serikat juga mulai melibatkan diri untuk mendukung programprogram yang diusung pemerintah. Confucius Institute juga secara langsung turut mengambil peran dalam kebijakan NSLI tersebut dengan melakukan kerjasama secara inisiatif kepada institusi atau lembaga yang berwenang untuk menjalankan programprogram NSLI yang ada. Salah satunya pada program Start Talking! (STARTALK) yang dikomandoi oleh Badan Intelijen Nasional Amerika Serikat. STARTALK secara serentak dijalankan oleh beberapa universitas dan institutsi di beberapa negara bagian Amerika Serikat yang dikomandoi oleh National Foreign Language Center berlokasi di Universitas Maryland dengan alokasi dana yang 
diberikan setiap institusi berkisar $\$ 50.000$ hingga $\$ 90.000$ tiap tahunnya (STARTALK 2016). Confucius Institute di universitasuniversitas tertentu kemudian mendaftarkan diri dengan mengirim proposal kepada Badan Intelijen Amerika Serikat. Dalam menjalankan program tersebut, universitas-universitas kemudian memberi wewenang kepada setiap unit Confucius Institute yang telah ada untuk bidang bahasa dan budaya China. Confucius Institute juga yang kemudian secara penuh dan independen menciptakan kurikulum yang sesuai dengan misi dan tujuan dari program STARTALK. Hingga tahun 2015, terdapat 27 unit Confucius Institute yang rutin setiap tahun bekerjasama dan menyelenggarakan program STARTALK.

Selain program STARTALK, Confucius Institute juga menjalin kerja sama pada program NSLI-Youth yang dikomandoi oleh Departemen Luar Negeri Amerika Serikat. Dalam situs NSLI-Youth, dijelaskan bahwa yang menjadi partner program yang bertanggung jawab dan mengimplementasikan program NSLI-Youth pada bidang pendidikan budaya dan bahasa China adalah Confucius Institute Universitas Delaware dan Confucius Institute Universitas Minnesota. Kedua Confucius Institute tersebut yang kemudian mengatur segala bentuk kurikulum, aktifitas dan akomodasi yang dilakukan selama program NSLI-Youth berlangsung tiap tahunnya. Setiap tahunnya juga, universitas atau institusi yang menjadi implementer program NSLI-Youth mendapatkan dana dari Departemen Luar Negeri. Sejak 2007 hingga 2015, Universitas Delaware yang menjadi salah satu implementer program ini mendapatkan total dana sebesar lebih dari \$1,5 juta dengan rata-rata sekitar $\$ 200.000$ - $\$ 300.000$ di tiap tahunnya (Bryan 2012). Dana tersebut yang kemudian digunakan Confucius Institute Universitas Delaware untuk melaksanakan dan memfasilitasi program NSLI-Youth yang berfokus pada kegiatankegiatan pertukaran pelajar musim panas di negara China (Laws 2016). Direktur Confucius Institute Universitas Delaware, Jianguo Chen (dalam Briyan 2012) juga menyebutkan: "In promoting 'cultural diplomacy,' our goal is to facilitate understanding and exchange, particularly in terms of mutual trust and cooperation."

Selain melakukan kerjasama secara inisiatif, Confucius Institute juga terlibat dalam penawaran kerjasama yang dilakukan oleh sekolahsekolah di Amerika Serikat untuk implementasi program Foreign Language Assistance Program. Sekolah-sekolah yang ada menawarkandiri untuk bekerjasama dengan Confucius Institute universitas tertentu dalam melaksanakan program FLAP tersebut. Seperti yang dilakukan oleh Utica Community School yang merupakan distrik sekolah di Detroit yang bekerjasama dengan Confucius Institute 
Michigan State University pada tahun 2007 (U.S. Department of Education 2008). Memphis City School yang bekerjasama dengan Confucius Institute University of Memphispada tahun 2008 (U.S. Department of Education 2008). Seattle Public School yang bekerja sama dengan Confucius Institute of the State of Washington pada tahun 2011 (Confucius Institute of the State of Washington 2011). Hopskins School District, Minnetonka School District, dan St. Cloud Public Schools yang bekerjasama dengan Confucius Institute University of Minnesotapada tahun 2009 (University of Minnesota 2009). Distrik-distrik sekolah tersebut kemudian menerima dana dari Departemen Pendidikan Amerika Serikat sebesar 1,4 juta dollar untuk 5 tahun dan memberi wewenang Confucius Institute untuk menjalankan aktivitas pendidikan bahasa di bidang bahasa China yang telah disesuaikan dengan misi dan tujuanprogram FLAP ke dalam aktivitas pembelajaran distrik sekolah mereka. Alasan utama distrik-distrik sekolah tersebut bekerjasama karena Confucius Institute dinilai memiliki fasilitas dan kinerja yang baik dalam bidang pendidikan bahasa China jika dibandingkan dengan institusi bahasa China lainnya.

Confucius Institute juga berkontribusi dalam perkembangan pendidikan bahasa mandarin pada level pendidikan tinggi ke bawah di Amerika Serikat. Confucius Classroom merupakan bentuk subsidiaris Confucius Institute dengan target pelajar sekolah dasar hingga menengah keatas. Amerika Serikat memiliki jumlah unit Confucius Classroom terbesar di tingkat global, terdapat 347 unit dari total 1000 unit di dunia, atau sepertiga jumlah Confucius Classroom secara global berada di Amerika Serikat. Confucius Classroom berkontribusi dalam persebaran pendidikan bahasa China di tingkat sekolah-sekolah, terutama pada sekolah negeri. Hal ini mengingat hanya sedikit sekolah-sekolah publik di Amerika Serikat yang memasukkan pendidikan bahasa asing di kurikulum mereka. Seperti yang disampaikan oleh Menteri Pendidikan Amerika Serikat Arne Duncan pada pidatonya di Foreign Language Summit (dalam U.S. Department of Education 2010):

"Foreign language instruction in the United States is spotty and unfortunately on the decline. In 2008, one-quarter of elementary schools offered some form of language instruction - down from one-third 11 years earlier. Just 10 states require foreign language study for high school graduation--and lowincome and minority students in particular lag behind their peers in other countries in their knowledge of languages, as well as geography and other cultures." 
Perkembangan dari Confucius Classroom di Amerika Serikat sendiri tidak terlepas dari peran inisiatif Confucius Institute universitas host country dalam melakukan sosialisai program Confucius Classroom ke berbagai sekolah di negara bagian mereka. Setelah itu, sekolah yang tertarik mendirikan Confucius Classroom kemudian mengirimkan proposal kepada Hanban melalui Confucius Institute tertentu yang mereka ingin bekerja sama. Perkembangan Confucius Classroom di Amerika Serikat sendiri mendapat respon positif dengan semakin banyaknya sekolah yang mendaftar untuk mendirikan program tersebut. Adapun kontribusi Confucius Classroom bagi pendidikan bahasa asing di Amerika Serikat sendiri seperti yang di-sebutkan oleh Rektor dari University of Maryland (dalam Ying 2014):

"I think the special value is bringing Chinese language to the public schools. Without Confucius Institutes, there would not be much Chinese language instruction in American public schools".

Bentuk kontribusi baik Confucius Institute dan Confucius Classroom berbagai macam. Di negara bagian Florida, sejak tahun 2008, berbagai bantuan dan program dalam meningkatkan pendidikan bahasa China telah dilakukan oleh Confucius Institute University of South Florida(USF) seperti; (1) Bekerjasama dengan 10 sekolah di Florida untuk melakukan aktifitas kegiatan kultural, dengan jumlah keikutsertaan lebih dari 2000 pelajar dan anggota keluarga tiap tahunnya; (2) Mendirikan program pendidikan untukpengembangan profesi pengajar bahasa China pada level K-12; (3) Menaungi tiga Confucius Classrooms di Tampa Bay; (4) Menggelar kompetensi bahasa China dengan Florida Chinese Teachears Association dan memprakarsai penghargaan "Teachers of the Year Award" di tiap tahunnya (University of South Florida 2014). Aktifitas yang dilakukan oleh Confucius Institute USF tersebut juga dibarengi dengan peningkatan jumlah pelajar yang mengikuti mata pelajar pendidikan bahasa China secara signifikan di tiap tahunnya. Pada tahun mata pelajaran 2013-2014 tercatat 8011 pelajar sekolah publik di florida yang memelajari bahasa China. Hal ini meningkat drastis dari sejak Confucius Institute University of South Florida mulai berdiri pada tahun 2010.

Hal yang serupa juga dilakukan oleh Confucius Institute University California Los Angeles (UCLA), khususnya dalam hal pengembangan sumber daya materi dan pengajar bahasa China. Pada 2009, Confucius Institute UCLA melakukan internalisasi materi sesuai denganWorld Language Content Standard (WCLS), selain itu 
Confucius Institute UCLA juga memprakasai pendirian Mandarin Teacher Leadership Institute yang bertujuan untuk melatih baik pengajar maupun calon pengajar bahasa China di California sebagai upaya penyelarasan kurikulum WCLS secara profesional (UCLA Confucius Institute $t, t)$. Confucius Institute UCLA juga melakukan publikasi buku secara masif mengenai pengobatan tradisional China yang dialihbahasakan Inggris-Mandarin dan Mandarin-Inggris untuk fakultas kedokteran di universitas-universitas California sehingga diharapkan memperkaya wawasan bagi penelitian terminologi medis (UCLA Confucius Institute $t, t$ ).

\section{Grafik 1. Peningkatan pelajar dalam Pendidikan Bahasa China di Sekolah Publik Florida}

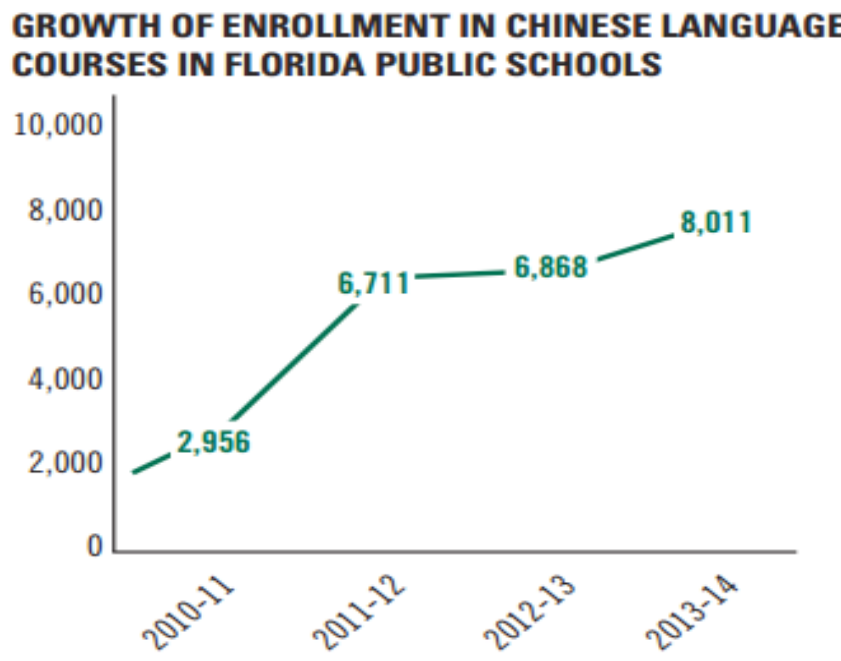

Sumber: USF Annual Report, 2014

\section{Strategi Marketing Mix: Adaptasi Confucius Institute Di Amerika Serikat}

Confucius Institute sebagai lembaga bahasa asing milik pemerintah yang menempati posisi terbesar di Amerka Serikat tentu tidak terlepas dari strategi-strategi yang dijalankan sehingga menempati posisi tersebut. Madam Xu Lin, Direktur Umum Confucius Institute menyatakan bahwa perkembangan Confucius Institute tidak terlepas dari upaya kedua belah pihak (Universitas China dan Amerika Serikat) yang selalu melakukan inovasi-inovasi terhadap pembelajaran di dalam kelas Confucius Institute itu sendiri sehingga meningkatkan minat masyarakat dalam mempelajari budaya dan bahasa China di Confucius Institute Amerika Serikat (Hanban News 2010). 
Masing-masing universitas dan institusi yang ada di Amerika Serikat memiliki program-program khusus yang menarik sehingga aktifitas pembelajaran pun tidak monoton dan berlangsung secara interaktif. Selain itu aktifitas kerjasama dan pemasaran pun juga secara aktif dilakukan oleh Confucius Institute Amerika Serikat.

Penulis kemudian menganalisa bagaimana aktivitas pemasaran yang Confucius Institute lakukan dengan menggunakan pandangan marketing mix yang umumnya diterapkan sebagai langkah adaptasi produk dan pemasaran dalam melakukan bisnis yang dilakukan oleh anak perusahaan di host country. Penulis kemudian menganalisis bentuk marketing mix yang dilakukan oleh Confucius Institue di Amerika Serikat dengan marketing mix 4P's dan 4C's. Marketing mix ini memiliki variabel yang saling terkolerasi dari dua sudut pandang yang berbeda antara Perusahan dengan Konsumen. Variabel tersebut adalah; (1) Produk yang dijual/ditawarkan adalah kebutuhan konsumen (Product = Costumer needs and wants); (2) Harga adalah biaya yang dikeluarkan konsumen (Price = Customer cost); (3) Proses distribusi dan penempatan produk mendukung kenyamanan aksesbilitas konsumen (Place = Convenience) dan; (4) Promosi yang dilakukan perusahaan atau institusi yang berfokus pada menjalin komunikasi interaktif dengan calon konsumen (Promotion $=$ Communication) (The Marketing Mix 2016).

\section{Product $=$ Customer Needs}

Dalam melakukan kerjasama antara institusi China dengan institusi host country, Hanban memberikan konstitusi sebagai landasan kesepakatan antara kedua belah pihak yang bersifat universal. Pada Chapter 3 yang berisi kesepakatan mengenai business service, Hanban mewajibkan setiap unit Confucius Institute untuk melakukan beberapa hal terkait bisnis jasa kursusnya, seperti menyedia kan kursus bahasa China, melakukan pelatihan terhadap pengajar bahasa dan menyediakan materi bahasa, melakukan tes HSK (Chinese Proficiency Test) dan tes untuk sertifikasi pengajar bahasa, menyediakan informasi dan pelayanan konsultatif terkait pendidikan dan budaya China, serta melakukan student exchange antara China dengan negara lain (Confucius Institute t,t). Dari situ secara jelas terlihat mengenai jasa produk yang ditawarkan oleh masingmasing Confucius Institute di seluruh dunia adalah sama. Namun, hal tersebut tidak berarti bahwa Confucius Institute tidak dapat secara mandiri membentuk kebijakan terkait jasa kursusnya. Pada Chapter 8 dalam konstitusi tersebut mengenai supplement, disebutkan bahwa: 
"Individual Confucius Institutes may constitute their own regulations and measures in accordance with this Constitution and By-Laws and submit to the Headquarters for archiving purpose”.

Hal ini berarti bahwa setiap individu Confucius Institute berhak untuk membuat kebijakannya sendiri asalkan tidak melanggar halhal yang ada dalam konstitusi yang dibuat oleh Hanban, termasuk bentuk jasa kursus yang khusus yang ditawarkan.

Bentuk jasa produk yang ditawarkan masing-masing Confucius Institute sangat variatif dan tidak hanya berfokus pada bidang bahasa saja, namun juga pada aspek budaya China. Pada umumnya pembelajaran bahasa mandarin di Confucius Institute terbagi menjadi dua kategori, yaitu basic/introduction Chinese I dan II serta Intermediate Chinese I dan II sebagai materi pokok dalam HSK yang menjadi kewajiban masing-masing Confucius Institute.Di Amerika Serikat, Confucius Institute memiliki program-program yang memiliki ciri khas tersendiri yang terbagi menjadi dua macam, yaitu kursus bahasa mandarin dan kursus budaya mandarin yang rutin diadakan setiap minggunya. Penulis kemudian mengambil sampel 30 dari 109 unit Confucius Institute di negara-negara bagian yang ada di Amerika Serikat untuk melihat pola program-program khusus yang ditawarkan. Dari 30 sampel unit Confucius Institute pada kategori program bahasa mandarin 17 unit diantaranya menawarkan program bahasa mandarin khusus bisnis. Program ini menawarkan metode pembelajan bahasa mandarin yang berfokus pada bahasa ekonomi dan bahasa yang sering digunakan oleh para pengusaha serta bahasa manajemen lainnya.

Bahasa China mengenai bisnis memang menjadi hal yang semakin dibutuhkan oleh masyarakat Amerika Serikat, terutama yang memiliki minat menjalin hubungan ekonomi ataupun karir dengan perusahaan-perusahaan China di Amerika Serikat. China telah mengalami pertumbuhan ekonomi yang besar sejak awal abad 21 setelah Deng Xiaoping membuka perekonomian China terhadap global sekaligus mendorong industri export oriented. Pada tahun 2010 China mejadi negara ekonomi terbesar kedua mengalahi Jepang dan juga Jerman sebagai negara eksportir terbesar di dunia. Hubungan dinamis antara Amerika Serikat dengan China juga bergantung pada hubungan bisnis antara keduanya, banyaknya FDI yang keluar masuk dari dan ke China dan Amerika Serikat menjadikan interaksi antara aktor sebagai konsumen maupun investor di kedua negara tidak terhindari (Boston University 2016). 
Eksistensi perusahaan-perusahaan China di Amerika Serikat juga semakin tahun semakin besar. Tidak sedikit juga perusahaanperusahaan Amerika Serikat yang saat ini telah diakuisisi oleh perusahaan China seperti perusahaan Starwood Hotels, Smiltfield Foods, Ingram Micro, General Electic Appliance Business, Terex Corp, Legendary Entertainment Group, Motorola Mobility, AMC Entertainments Holding dan lain-lain membuat pengaruh China dalam bisnis Amerika Serikat semakin besar (Gandel 2016). Selain itu, banyaknya perusahaan-perusahaan di Amerika Serikat saat ini lebih menyukai calon karyawan yang memiliki kemampuan bilingual bahasa. Pada tahun 2010 tercatat sebanyak 39\% perusahaanperusahaan di Amerika Serikat memasukkan kemampuan bilingual pada kualifikasi lowongan pekerjaan, termasuk bahasa mandarin (Lee 2010). Sehingga menjadi sebuah kebutuhan bagi masyarakat Amerika Serikat, terutama pelajar dan mahasiswa untuk belajar bahasa asing untuk meningkatkan kemungkinan kesuksesan karirnya. Hal ini yang kemudian mendorong Confucius Institute untuk membuka program kursus bahasa mandarin yang berfokus pada bidang bisnis dengan tujuan untuk menjembatani China dengan perkembangan perekonomian dunia seperti yang tertera dalam situs Hanban (2015):

".....many Confucius Institutes now train students in business, tourism, and trade as well as language, martial arts, and calligraphy. As China opens itself more to the world, the Confucius Institute will become a link in the chain connecting China with world economic development."

Selain program kursus bahasa mandarin untuk bisnis, tidak sedikit Confucius Institute di Amerika Serikat yang berfokus pada program kursus budaya. Dari sampel 30 unit Confucius Institute Amerika Serikat hampir semua unit memiliki program kursus budaya China seperti seni beladiri, kaligrafi, kuliner, musik dan tari. Hal tersebut karena secara umum jumlah peminat pembelajaran budaya lebih besar daripada peminat bahasa itu sendiri. Ditambah dengan besarnya jumlah Confucius Institute di suatu negara di kota yang sama dan di negara bagian yang sama menyebabkan semakin sulit untuk menarik minat masyarakat apabila unit individu Confucius Institute tersebut tidak memiliki daya khas atau ciri khusus dalam penawaran program-program yang ada (Hartig 2015). Hal inilah yang menjadi faktor utama Confucius Institute di Amerika Serikat menawarkan berbagai program yang unik dengan tujuan untuk meningkatkan minat masyarakat Amerika Serikat untuk mendaftar. 


\section{Price $=$ Customer cost}

Variabel kedua dalam strategi marketing mix 4P's\&4C's adalah harga yang sesuai dengan daya beli konsumen. Setelah penentuan produk, langkah selanjutnya adalah dengan menentukan harga produk tersebut secara tepat dan efisien sesuai dengan daya beli calon konsumen (Emmerson 2016). Dalam hal ini, yang menjadi pertimbangan utama adalah dengan membandingkan dengan harga produk kompetitor yang sejenis dan melihat rata-rata pendapatan masyarakat Amerika Serikat. Penulis kemudian membandingkan rata-rata harga program kursus reguler dalam periode rata-rata 1 semester yang ditetapkan oleh Confucius Institute di Amerika Serikat dengan kompetitor lembaga bahasa lain yang telah terkenal baik dengan bahasa mandarin maupun non bahasa mandarin yang ada di Amerika Serikat.

\section{Tabel 4. Perbandingan harga institusi bahasa non China di Amerika Serikat.}

\begin{tabular}{|c|c|c|c|}
\hline $\begin{array}{c}\text { Confucius } \\
\text { Institute }\end{array}$ & $\begin{array}{c}\text { Cervantes } \\
\text { Institute }\end{array}$ & $\begin{array}{c}\text { Goethe } \\
\text { Institute }\end{array}$ & $\begin{array}{c}\text { Institute } \\
\text { Francais }\end{array}$ \\
\hline$\$ 50-\$ 250$ & $\$ 425-580$ & $\$ 530-1200$ & $\$ 650$ \\
\hline
\end{tabular}

\section{Tabel 5. Perbandingan harga institusi bahasa China di Amerika Serikat}

\begin{tabular}{|c|c|c|c|}
\hline $\begin{array}{c}\text { Confucius } \\
\text { Institute }\end{array}$ & $\begin{array}{c}\text { Chinese American } \\
\text { Service League }\end{array}$ & $\begin{array}{c}\text { South Bay } \\
\text { Chinese School }\end{array}$ & $\begin{array}{c}\text { American } \\
\text { Chinese School }\end{array}$ \\
\hline$\$ 50-\$ 250$ & $\$ 400$ & $\$ 500-600$ & $\$ 1125-\$ 1350$ \\
\hline
\end{tabular}

Dari tabel diatas, terlihat bahwa harga yang ditawarkan oleh Confucius Institute merupakan harga yang termurah dari seluruh institusi diatas kendati Confucius Institute merupakan kompetitor baru di industri kursus bahasa. Produk jasa yang variatif yang tentunya memiliki harga tersendiri menjadikan program reguler Confucius Institute di Amerika Serikat lebih murah. Dalam hal ini, Confucius Institute terbukti mampu untuk bersaing dengan kompetitornya, baik sejenis (budaya dan bahasa China) maupun tidak dengan biaya yang lebih murah pada selisih harga yang cukup jauh.

Dari segi rata-rata pendapatan masyarakat Amerika Serikat, harga yang ditetapkan oleh Confucius Institute merupakan harga yang dapat dijangkau oleh mayoritas masyarakat. Sebanyak 42,87\% dari total penduduk Amerika Serikat memiliki pendapatan rata-rata 
di bawah \$2500 hingga \$25.00o di tiap tahunnya (United States Census Bureau 2015). Dari 42,87\% tersebut, individu yang hanya memiliki rata-rata pendapatan sebesar $\$ 2500$ adalah angkatan yang terbesar yaitu sekitar 10\% atau sebanyak 20.951.000 penduduk Amerika Serikat. Jika dibandingkan harga-harga yang ada dengan rata-rata pendapatan mayoritas masyarakat, sangat sulit untuk mengatur keuangan jika masyarakat Amerika Serikat mendaftar ke institusi bahasa lain selain Confucius Institute, terutama untuk masyarakat yang rata-rata berpenghasilan $\$ 2500$ tiap tahunnya. Hal ini membuktikan juga bahwa harga yang ditentukan oleh Confucius Institute Amerika Serikat adalah harga yang bisa dijangkau oleh mayoritas masyarakat Amerika Serikat bahkan yang berpenghasilan rendah sekalipun. Price dalam hal ini terbukti terkolerasi dengan Customer Cost masyarakat Amerika Serikat.

\section{Place $=$ Convenience}

Place pada marketing mix umumnya berfokus pada bagaimana suatu produk didistribusikan dan seberapa strategis lokasi pendistribusian produk tersebut. Confucius Institute Amerika Serikat pada umumnya berlokasi di dalam atau di dekat wilayah universitas atau institusi Amerika Serikat (Sahlin 2013). Hal ini dikarenakan meskipun Confucius Institute terbuka untuk umum tetapi target atau sasaran utamanya adalah kalangan akademisi seperti pelajar atau mahasiswa. Dalam menganalisis variabel ini, penulis melihat dari perbandingan antara lokasi geografis Confucius Institute di Amerika Serikat dengan persebaran demografi pelajar asing yang berasal dari China yang menempuh pendidikan di Amerika Serikat.

\section{Gambar 4. Peta Persebaran Confucius Institute di Amerika Serikat}

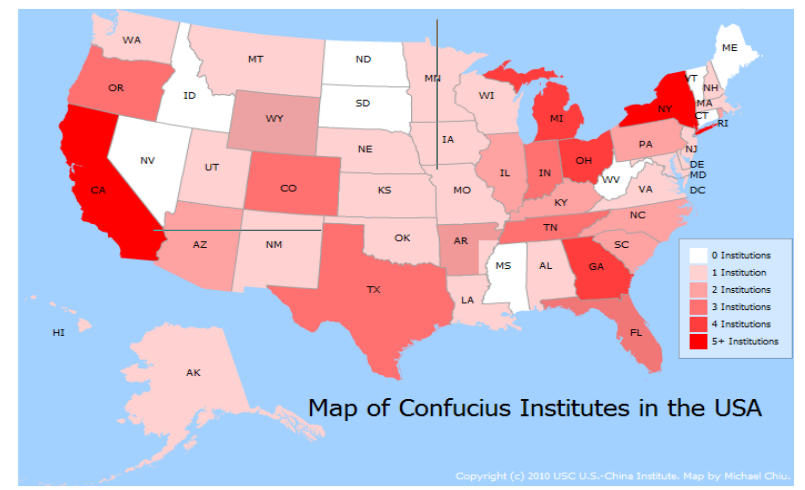

Sumber:http://uschina.usc.edu/w_usct/showarticle.aspx?articleID $=14774 \&$ AspxAutoDetectCookieSupport $=1$ 


\section{Gambar 5. Peta Persebaran pelajar China di Universitas Amerika Serikat}

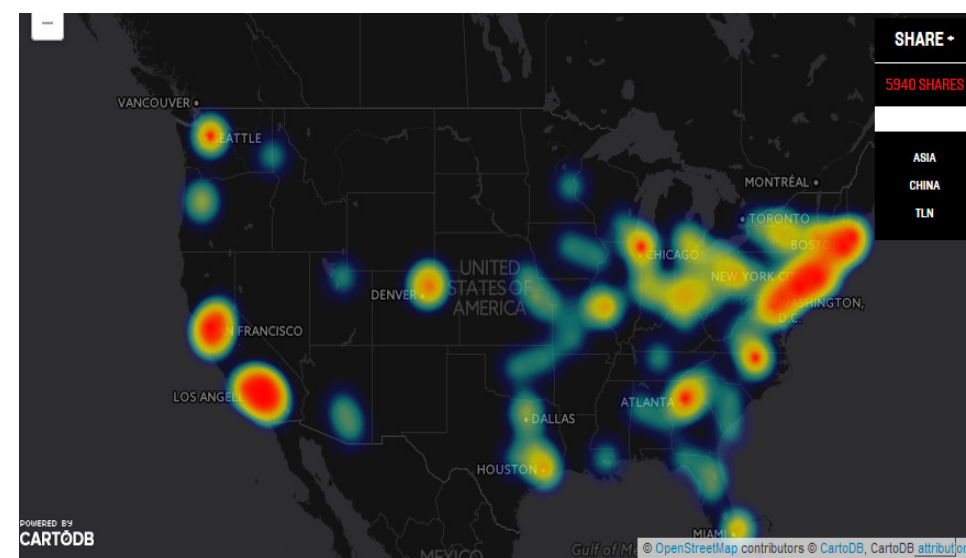

Sumber: http://foreignpolicy.com/2016/01/o4/the-most-chineseschools-in-america-rankings-data-education-china-u/

Dari dua peta tersebut, terlihat bahwa Confucius Institute cenderung didirikan di lokasi yang memiliki jumlah dominan pelajar asing termasuk pelajar asing China. Hal yang sama juga terlihat pada persebaran demografi pelajar asing China yang menempuh pendidikan tinggi di negara-negara bagian tersebut. Hal ini menyebabkan interaksi cross cultural adaptation tidak terhindari, antara pelajar Amerika Serikat dengan pelajar China yang bertemu satu sama lain cenderung melakukan adaptasi untuk memahami budaya dan bahasa yang berbeda. Bahasa Inggris yang telah mengglobal cenderung telah lebih dulu dipelajari dan dikuasai oleh banyak pelajar China sebelum menempuh pendidikan di Amerika Serikat namun mereka cenderung kurang percaya diri dalam hal speaking, sebaliknya hanya sedikit pelajar Amerika Serikat yang menguasai bahasa China namun cenderung berusaha untuk menjalin hubungan yang aktif (Yuan 2011). Kondisi ini dinilai strategis untuk mendirikan Confucius Institute oleh universitas-universitas di Amerika Serikat terutama universitas yang belum memiliki mata kuliah atau program bahasa dan budaya China.

Setiap universitas atau institusi Amerika Serikat juga cenderung mendirikan Confucius Institute berlokasi di dalam wilayah institusinya, baik di dalam gedung fakultas tertentu atau pendirian bangunan di sekitar wilayah kampus (Sahlin 2013). Seperti yang telah dijelaskan diatas bahwa Confucius Institute menargetkan pelajar atau mahasiswa untuk mendaftar meskipun masih tetap menerima masyarakat umum, sehingga kedekatan lokasi tempat berdirinya Confucius Institute dengan kampus atau institusi untuk memudahkan akses 
pelajar atau mahasiswa untuk pergi ke Confucius Institute menjadi prioritas utama meskipun tidak ada hukum tertulis dari Hanban yang menyatakan bahwa Confucius Institute harus berlokasi di dekat atau didalam kampus.

\section{Promotion $=$ Communication}

Variabel keempat dalam strategi marketing mix adalah promosi. Setiap perusahaan dalam melalukan pemasaran tentunya melakuka upaya-upaya promosi demi menarik minat masyarakat untuk membeli produk yang dihasilkan. Kegiatan promosi pada dasarnya memberikan segala bentuk informasi yang ada dalam aplikasi marketing mix, seperti produk apa yang dihasilkan, harga produk tersebut, dan dimana produk tersebut dapat dibeli atau dijumpai (Ehmke 2005).

Dalam melakukan kegiatan promosi, masing-masing individu Confucius Institute cenderung untuk melakukannya dengan kegiatan open house dan mengadakan event yang rutin diselenggarakan tiap tahun atau bahkan tiap bulan. Kegiatan-kegiatan tersebut tidak dipungut biaya dan terbuka untuk umum serta lebih bersifat kultural daripada bahasa. Metode-metode interaktif dan praktikal pun dilakukan oleh Confucius Institute di Amerika Serikat seperti mengadakan lomba-lomba dan workshop tentang budaya maupun pelatihan kerajinan tradisional Chinadengan tidak membatasi jumlah usia yang menghadiri acara tersebut. Hal tersebut seperti yang dilakukan oleh Confucius Institute Michigan State University yang mengadakan sekaligus mensponsori acara Dragon Boat Festival sekaligus mengadakan open house sebagai selebrasi 10 tahun berdirinya Confucius Institute di level global (Prawat 2012).

Namun, hal yang berbeda dilakukan oleh Confucius Institute West Kentucky University dalam mempromosikan program-program Confucius Institute nya. Apabila secara umum unit Confucius Institute lain lebih berfokus kepada cultural event yang diadakan secara open house maka Confucius Institute West Kentucky University mengedepankan aspek direct experience mobile yang dapat menyentuh seluruh masyarakat negara bagian Kentucky. Cara tersebut dilakukan dengan cara membentuk unit bis showroom yang berisi segala bentuk yang bertema China, baik itu bahasa maupun budaya. Alat transportasi yang dinamakan Chinese Cultural Experience atau masyarakat di sana sering menyebutnya dengan Confucius Institute Mobile juga telah sering melakukan pameran di daerah-daerah terpencil tempat dimana orang-orang semakin sedikit yang mengetahui Confucius Institute. 


\section{Gambar 6. Unit Confucius Institute Mobile yang dibentuk Confucius Institute West Kentucky University}

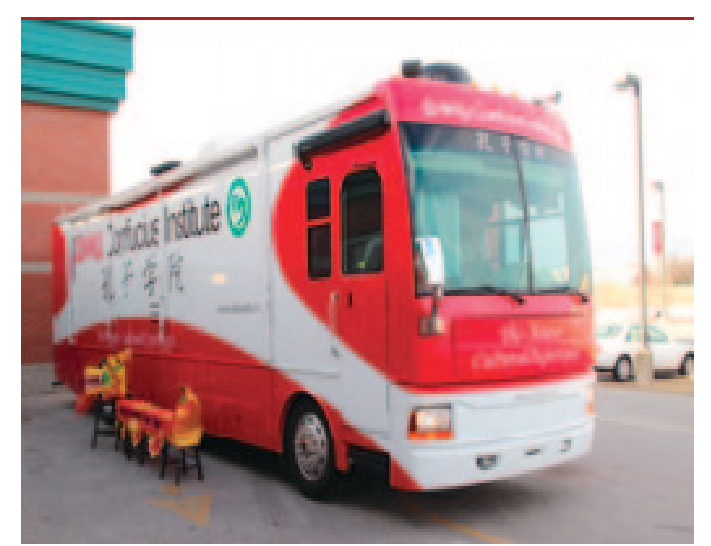

Sumber: Confucius Institute West Kentucky University

Annual Report, 2014

Unit ini secara khusus menjadi salah satu bentuk upaya promosi budaya China yang dilakukan Confucius Institute West Kentucky University kepada masyarakat luas di negara bagian Kentucky, secara khusus juga dalam buku laporan tahunan West Kentucky University (2015) disebutkan mengenai tujuan dibentuknya Confucius Institute Mobile Unit:

"The fundamental purpose of the Confucius Institute Mobile Unit "The Chinese Cultural Experience" is to establish a new innovative and economic unit, which will be transported strategically throughtout the state of Kentucky to promote the Chinese language and culture".

Di dalam unit tersebut, terbagi enam kompartemen yaitu instrumen musikal tradisional China, Kaligrafi China, Kesenian dan Kerajinan, Kostum-kostum tradisional China, Fakta-fakta budaya China dan Obat-obat traditional China. Terdapat pegawai atau tour guide yang menjelaskan setiap kompartemen yang ada, dan aktifitas ini tidak dipungut biaya. Mobil ini setiap minggunya beroperasi 2-3 kali bergantung jadwal yang ditentukan oleh Confucius Institute West Kentucky University. Komunitas atau institutsi di Kentucky juga dapat melakukan reservasi terhadap unit ini pada suatu event atau acara tertentu dengan menghubungi ke Confucius Institute West Kentucky University (West Kentucky University 2014). 


\section{Gambar 7. Kompartemen-kompartemen yang ada di dalam Confucius Institute Mobile}
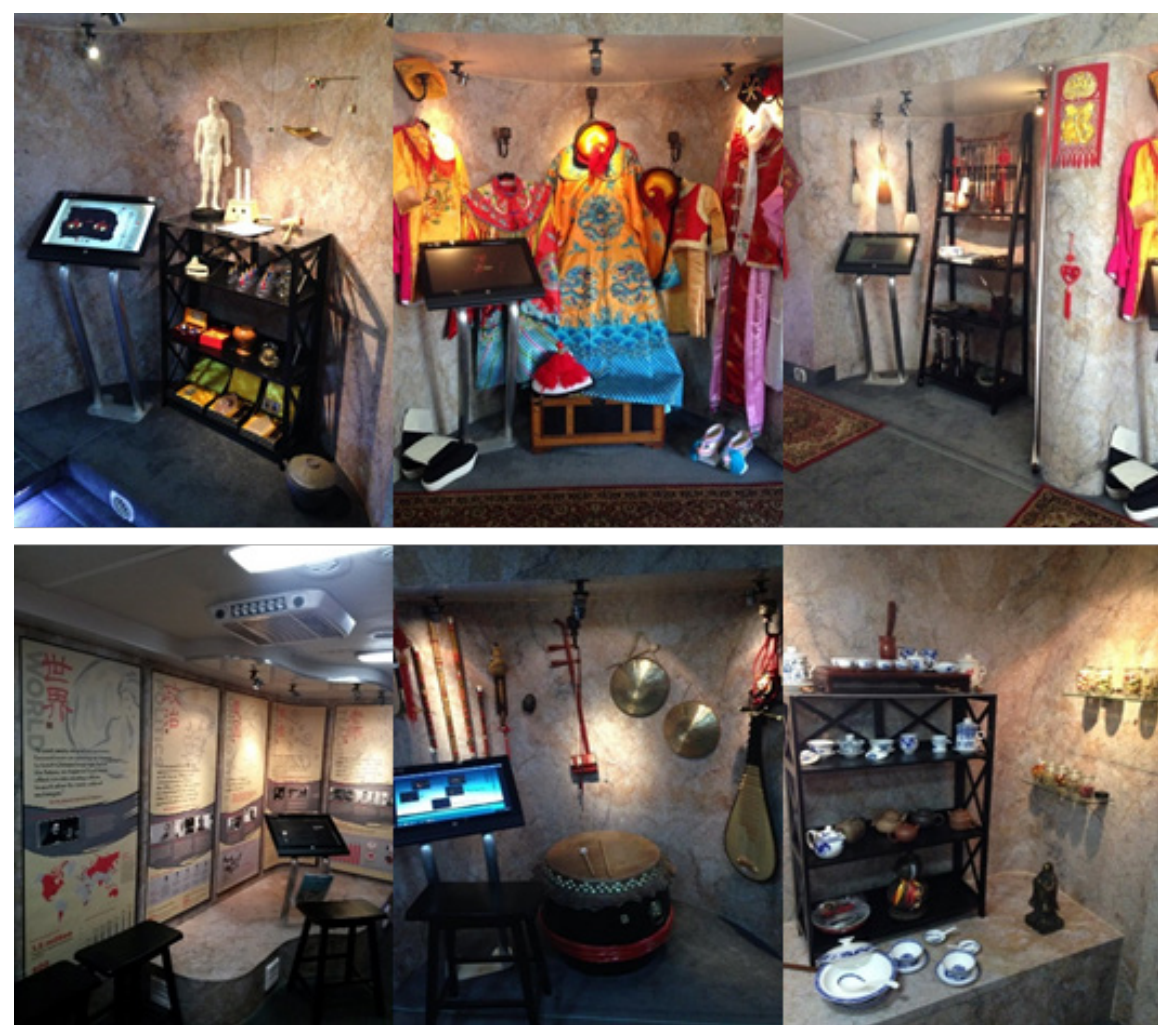

Sumber: https://www.wku.edu/ci/mobileci.php

Tidak hanya berhenti pada Confucius Institute Mobile, Confucius Institute West Kentucky University juga berencana untuk membangun sebuah unit truk yang berfokus untuk memperkenalkan makanan tradisional China yang disebut dengan The Confuucius Mobile Kitchen. Meski masih dalam bentuk prototype, unit ini rencananya akan diresmikan pada pertengahan tahun 2016. Kegiatan dari The Confucius Mobile Kitchen sendiri adalah memberi pengarahan tentang bagaimana cara memasak makanan China yang targetnya adalah masyarakat West Kentucky dan pelajar-pelajar di sekitar Confucius Institute maupun Confucius Classroom yang ada di negara bagian tersebut. Dana dari pembangunan uni ini bersumber dari fund raising oleh kelompok karyawan yang dibentuk Confucius Institute West Kentucky University dengan menjual berbagai macam makanan China dalam pada festival-festival maupun acara-acara tertentu di West Kentucky (West Kentucky University 2015). Adapun motto dari unit The Confucius Mobile Kitchen ini adalah "What Better Way to Connect and Share Culture Than Through Food" semakin memperjelaskan tujuan dari dibentuknya unit tersebut. 


\section{Gambar Prototype unit The Confucius Mobile Kitchen}

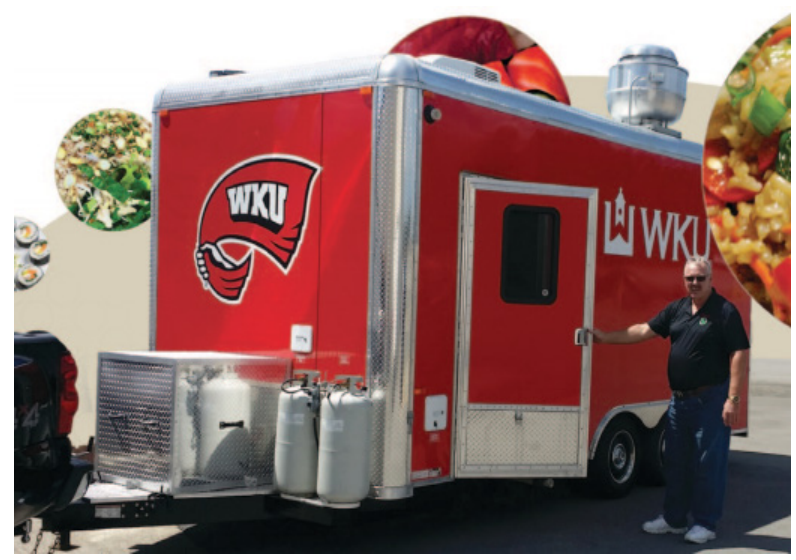

Sumber: Confucius Institute West Kentucky University

Annual Report, 2015

\section{Kesimpulan}

Dari pembahasan yang telah penulis jabarkan, maka dapat ditemui penjelasan bahwa perkembangan Confucius Institute yang pesat di Amerika Serikat ditunjang oleh aktivitas internasionalisasi pendidikan bahasa dan budaya China yang berfokus pada terjalinnya hubungan dan kerjasama bilateral antara home country dan host country, yakni China dengan Amerika Serikat dalam rangka menciptakan situasi dan kondisi yang mendukung untuk Confucius Institute berkembang, hubungan yang harmonis antara Confucius Institute dengan pemerintah Amerika Serikat melalui berbagai kerja sama yang sejalan dengan kebijakan pemerintah serta kontribusi Confucius Institute dalam perkembangan pendidikan bahasa asing bagi masyarakat Amerika Serikat yang selama ini belum dapat dilakukan dengan baik oleh pemerintah Amerika Serikat, serta penerapan strategi marketing mix sebagai upaya adaptasi dengan kebutuhan, kondisi, dan minat masyarakat Amerika Serikat.

Dalam aplikasi two-tier bargaining model, penulis menemukan bukti bahwa home country yaitu China telah menjalin kedekatan hubungan dengan host country, yakni Amerika Serikat. Hubungan ini terlihat dari hubungan diplomatik kedua negara, seperti kunjungan antara kepala pemerintahan yang intens dilakukan serta dengan berbagai kerjasama mengenai pendidikan dan pertukaran pelajar yang ada. Dari kerjasama tersebut dapat dilihat bahwa negara baik secara langsung maupun tidak langsung mengakui keberadaan Confucius Institute serta memberikan fasilitas kerjasama pendidikan yang dapat dimanfaatkan oleh Confucius Institute untuk berkembang dan 
dikenal oleh masyarakat sehingga menciptakan kondisi yang sangat mendukung Confucius Institute untuk berkembang.

Penulis juga mendapatkan bukti kedekatan Confucius Institute dengan pemerintah maupun masyarakat Amerika Serikat sebagai aplikasi tier selanjutnya dalam bargaining model. Kebijakan Amerika Serikat yang memiliki program-program pengembangan pendidikan bahasa asing dimanfaatkan oleh Confucius Institute dan universitas host country-nya untuk terlibat aktif dalam programprogram tersebut. Pemerintah pun menyetujui dan memberikan alokasi dana yang cukup sebagai upaya implementasi tersebut. Kemampuan Confucius Institute sebagai fasilitator yang dinilai baik sekaligus kontribusi Confucius Institute dalam perkembangan pendidikan bahasa asing di level grassroot melalui Confucius Classroomjuga menjadi bargain power tersendiri yang dimilikinya.

Aplikasi marketing mix sebagai strategi pemasaran dalam upaya internasionalisasi yang berfokus pada adaptasi dengan kebutuhan, kondisi, dan minat masyarakat Amerika Serikat menjelaskan bagaimana Confucius Institute dapat diterima dengan baik oleh calon konsumennya yaitu masyarakat Amerika Serikat. Strategi marketing mix dengan variabel 4P's\&4C's dapat menjelaskan dari dua sisi yang saling berkesinambungan, yaitu sisi perusahaan atau institusi melalui variabel 4P's dan sisi konsumen melalui variabel 4C's, sehingga dapat diketahui secara lebih jelas mengapa konsumen harus menggunakan produk yang ditawarkan, dalam hal ini adalah Confucius Institute. Aplikasi dari strategi adaptasi marketing mix yang menawarkan variatif produk jasa Confucius Institute yang sesuai dengan kebutuhan dan minat masyarakat, seperti produk jasa chinese business school yang dibutuhkan berdasarkan lowongan pekerjaan perusahaan-perusahaan di Amerika Serikat yang lebih menyukai calon karyawan yang memiliki kemampuan bilingual, harga Confucius Institute yang lebih murah dibanding dengan lembaga bahasa lainnya baik yang sejenis maupun tidak dengan melihat daya beli masyarakat melalui pendapatan rata-rata per tahunnya, distribusi Confucius Institute berdiri yang mudah diakses oleh target pasar utama yaitu pelajar dan mahasiswa serta sesuai dengan kondisi yang ada, hingga strategi promosi yang berfokus pada komunikasi interaktif dengan calon konsumen melalui berbagai macam bentuk. 


\section{Daftar Pustaka}

\section{Artikel Daring}

Boston University. 2016. "Why Study Chinese”. [daring]. Tersedia di: https://www.bu.edu/mlcl/home/why-study-chinese/ [Diakses pada 9 Juni 2016].

Bryan, Tracey. 2012. "Cultural Diplomacy: UD leads American Cultural Diplomacy Institute in China This Summer". [daring]. Tersedia di: http://www1.udel.edu/udaily/2012/jun/china-institute-062812.html [Diakses pada 28 September 2016].

Confucius Institute. T,t. "Constitution and By-Laws of the Confucius Institute". [daring]. Tersedia di: http://english.hanban. org/node_7880.htm [Diakses pada 7 Juni 2016].

Confucius Institute Headquarter. T,t. "Confucius Institute and Classroom". [daring]. Tersedia di: http://english.hanban.org/ node_10971.htm [Diakses pada 28 Mei 2016].

Confucius Institute of the State of Washington. 2011. "LEA-IHE Foreign Language Assistance Program (FLAP) Foreign Language Methods Course and Practicum". Tersedia di: http://confucius.washington.edu/lea-ihe/ [Diakses pada 10 Desember 2016].

Emerson, Melinda. 2016. "The Five Ps of Marketing: Product, Place, Promotion, Price and Profit”. [daring]. Tersedia di: http://www.inc.com/theupsstore/the-five-ps-of-marketing-product-place-promotion-price-and-profit.html. [Diakses pada 9 Juni 2016].

Gallup Poll. T,t. "China”. [daring]. Tersedia di: http://www.gallup. com/poll/1627/china.aspx [Diakses pada 2 Desember 2016].

Hanban News. 2015. "Confucius Institute: Bring Class to The World (Education Vision)". [Daring]. Tersedia di: http://english.hanban.org/article/2015-12/31/content_628834. htm. Diakses pada 9 Juni 2016.

Hanban News. 2010. "Director-General of Hanban Madame Xu Lin: "Quantity and Quality of Chinese Promotion Are of Equal Importance"”. [daring]. Tersedia di: http://english.hanban.org/article/2010-04/26/content_146484. 
htm [Diakses pada 10 Juni 2016].

Hanban News, 2015. "Recuritment Procedures for Confucius Institute Scholarship". [Daring]. Tersedia di: http://english. hanban.org/article/2015-03/12/content_581006.htm [Diakses pada 15 Juni 2016].

Jennewein, Chris. 2015. "More Immigrants Coming from China India Now Than Mexico". [Daring]. Tersedia di: http:// timesofsandiego.com/politics/2015/05/05/more-immigrants-coming-from-china-india-now-than-mexico/ [Diakses pada 10 Mei 2015].

Laws, Nikki. 2016. "National Initiative: UD receives grant to host language immersion program at Xiamen". [Daring]. Tersedia di: http://www.udel.edu/udaily/2016/june/ nsliy-ud-xiamen/ [Diakses pada 28 September 2016].

Lee, Edmund. 2010. "Learning Chinese: Will You Make More Money?”. [Daring]. Tersedia di: http://www.cbsnews.com/ news/learning-chinese-will-you-make-more-money/. [Diakses pada 9 Juni 2016].

Sahlins, Marshal. 2013. "China U.”. [daring]. Tersedia di: https:// www.thenation.com/article/china-u/ [Diakses pada 1 Desember 2016].

Scotton, James F. 2015. "Confucius Institute and China's Soft Power". [Daring]. Tersedia di: https://blogs.nottingham.ac.uk/ chinapolicyinstitute/2015/07/01/confucius-institutesand-chinas-soft-power/ [Diakses pada 4 Mei 2016].

Topping, Seymour. 2011. "China vs the US: The Roots of Love Hate Relationship". [Daring]. Tersedia di: http://www.worldpolicy.org/blog/2011/12/14/china-vs-us-roots-lovehate-relationship-part-1 [Diakses pada 10 Mei 2016].

UCLA Confucius Institute. T,t. "Programs”. [daring]. Tersedia di: http://www.confucius.ucla.edu/programs [Diakses pada 15 Desember 2016].

University of Maryland. N,d. "Confucius Classrooms" [daring]. Tersedia di: https://globalmaryland.umd.edu/offices/ confucius-institute-maryland/confucius-classrooms [Diakses pada 12 Juni 2016].

US-China Strong. T.t. "Signature Partners". [daring]. Tersedia di: 
http://10okstrong.org/initiatives/signature-partners/ [Diakses pada 5 Oktober 2016].

West Kentucky University. 2014. "Confucius Institute Mobile Unit: The Chinese Cultural Experience". [daring]. Tersedia di: https://www.wku.edu/ci/mobileci.php [Diakses pada 12 Juni 2016].

Ying, Sun. 2014. "Dr. Wallace D. Loh: Why do we need the Confucius Institute?”. [Daring]. Tersedia di: http://confuciusmag. com/the-need-for-confucius-institute [Diakses pada 28 September 2016].

\section{Buku}

Berger, Mark T. 2004. "The Battle for Asia: form decolonization to globalization”. RouledgeCurzon Taylor\&Francis Group: London. Pp 189.

Hartig, Falk. 2015. "Chinese Public Diplomacy: The Rise of Confucius Institute". Routledge: Taylor and Francis Group. London and New York.

McCarthy, E. J. 1960. "Basic Marketing, A Managerial Approach". Homewood, IL., Richard D.Irwin Publisher.

\section{Dokumen Pemerintah}

STARTALK. 2016. "Proposal Process and Program Requirements Overview". [pdf]. Didownload di: https://startalk.umd. edu/public/system/files/grantapplicationoverview.pdf [Diakses pada 23 September 2016].

The White House. 2002. "President Bush Speak at Tsinghua University". [daring]. Tersedia di: https://georgewbush-whitehouse.archives.gov/news/releases/2002/ 02/20020222.html [Diakses pada 3 Oktober 2016].

U.S. Department of Education. 2006. "Teaching Language for National Security and American Competitiveness". [PDF]. Didownload di:https://www2.ed.gov/teachers/ how/academic/foreign-language/teaching-language.pdf [Diakses pada 13 September 2016]. 
2008. "Project CLIME (Critical

Language Initiative in Mandarin Education) Utica Community School Foreign Language Assistence Program (2008-2013)". [Pdf]. Didownload di https://www2. ed.gov/policy/gen/leg/foia/flapleautica.pdf [Diakses pada 8 Desember 2016.

2008. "Memphis City School". [pdf]. Didownload di: https://www2.ed.gov/policy/gen/ leg/foia/flapleamemphis.pdf [Diakses pada 8 Desember 2016].

. 2009. "U.S. - China Workplan on Education Activities". [pdf]. Didownload di: http:// www2.ed.gov/about/inits/ed/internationaled/2009-uschina-work-plan.pdf [Diakses pada 5 Desember 2016].

. 2010. "Education and the Language Gap: Secretary Arne Duncan's Remarks at the Foreign Language Summit”. [daring]. Tersedia di: http:// www.ed.gov/news/speeches/education-and-languagegap-secretary-arne-duncans-remarks-foreign-languagesummit [Diakses pada 1 Oktober 2016].

U.S. Department of State. 2011. "100.00o Strong Initiative: Student Resources for Studying in China”. [daring]. Tersedia di: http://www.state.gov/p/eap/rls/2011/177633.htm [Diakses pada 23 September 2016].

United States Census Bureau. 2015. "PINC-01. Selected Characteristics of People 15 Years and Over, by Total Money Income, Work Experience, Race, Hispanic Origin, and Sex.”. [daring]. Tersedia di: http://www.census.gov/data/ tables/time-series/demo/income-poverty/cps-pinc/ pinc-01.html [Diakses pada 1 Desember 2016].

Victoria State Government. T,t. "Application Guidelines for Confucius Classroom Programs and Funding”. [PDF]. Di download di: https://www.eduweb.vic.gov.au/edulibrary/.../ confuciusclass.pdf [Diakses pada 11 Juni 2016]. 


\section{Jurnal}

Gandel, Stephen. "The Biggest America Companies Now Owned by The Chinese". [daring]. Tersedia di: http://fortune. com/2016/03/18/the-biggest-american-companiesnow-owned-by-the-chinese/ [Diakses pada 9 Juni 2016].

Gill, Bates. 2006. "Meeting The Challeges And Opportunites of China's Rise: Expanding and Improving Interaction between the American and Chinese policy Communities". Center for Strategic and International Studies. Washington,D.C. United States.

Joint National Committee for Languages. 2015. "The Contribution of Language to the Economic Interests of The United States. [pdf]. Di download di: https://www.amacad. org/multimedia/pdfs/TheContributionsofLanguagetotheEconomicInterestsoftheUnitedStates.pdf [Diakses pada 4 Oktober 2016].

Pan, Su Yan. 2013. "Confucius Institute Project: China's Cultural Diplomacy and Soft Power Projection". [PDF]. Di download di: https://www.ied.edu.hk/flass/fas_upload/userfiles/ pdf/Confucius\%2oInstitute\%2oproject.pdf. [Diakses pada tanggal 25 April 2016].

Prawat, Theodore. 2014. "Dragon Boat Festival Reflection". [PDF]. Didownload di: http://www.experiencechinese.com/index.php/publications [Diakses pada 12 Juni 2016].

Ramamurti, Ravi. 2001. "The Obsolescing 'Bargaining Model'? MNC-Host Developing Country Relations Revisited". Journal of International Business Studies, Vol. 32, No.1. Palgrave Macmillan Journals. Pp 23-39.

Task Force. 2007. "U.S.-China Relations: An Affirmative Agenda, A responsible Course". Council on Foreign Relations. New York. United States of America.

Yuan, Wenli. 2011. "Academic and Cultural Experiences of Chinese Student at an American University: A Qualitative Study". Intercultural Communication Studies XX: 1. Kean University USA.

Zaharna, R.S. 2014. "Confucius Institute and The Globalization of China Soft Power”. Figueroa Press. Los Angeles. Pp 15. 


\section{Laporan Tahunan}

University of Minnesota. 2009. "Confucius Institute University of Minnesota Annual Report 2008 - 2009”. [pdf]. Di download di: http://confucius.umn.edu/about/ [Diakses pada 12 Desember 2016].

University of South Florida. 2014. "USF World 2014-2015 Annual Report”. [pdf]. Di download di: www.usf.edu/world/ about/usfworld_2014-15_annualreport.pdf [Diakses pada 13 Desember 2016.

West Kentucky University. 2014. "Confucius Institute of West Kentucky University Annual Report”. [pdf]. Di download di: http://digitalcommons.wku.edu/ci_pubs/ [Diakses pada 20 Juni 2016]. 